\title{
Effects of trenbolone acetate and zeranol on protein metabolism in male castrate and female lambs
}

\author{
BY PATRICK A. SINNETT-SMITH, NICOLA W. DUMELOW AND \\ PETER J. BUTTERY
}

\author{
Department of Applied Biochemistry and Food Science, University of Nottingham School \\ of Agriculture, Sutton Bonington, Nr. Loughborough, Leics. LE12 5RD
}

(Received 19 May 1982 - Accepted 18 January 1983)

1. Tissue composition and skeletal muscle cathepsin $\mathrm{D}(E C 3.4 .23 .5)$ activity were measured in wether lambs treated with trenbolone acetate (TBA) and oestradiol-17 $\beta(\mathrm{Oe})$ in combination and female lambs treated with TBA or zeranol. Muscle and liver protein fractional synthesis rates and plasma leucine flux were measured in the female lambs.

2. Male castrate lambs treated with TBA plus Oe showed increased growth rate, improved food conversion efficiency, decreased muscle RNA concentration and decreased total cathepsin D activity in muscle.

3. Female lambs treated with TBA or zeranol showed increased weight gain, improved food conversion efficiency, decreased muscle RNA and DNA concentrations and decreased free cathepsin D activity in muscle. Mixed muscle protein fractional synthesis rate was decreased after TBA treatment. Plasma leucine flux, not corrected for oxidation or food intake, was not increased by TBA or zeranol treatment.

4. Treatment of female lambs with TBA or zeranol caused increased growth rate. This increased growth rate is probably due in part to decreased muscle protein degradation, since evidence was obtained that muscle protein synthesis is decreased by TBA and zeranol treatment.

Anabolic agents are widely used to increase productivity in farm animals (Heitzman, 1980). Implantation of trenbolone acetate (3-oxo-17 $\beta$-hydroxy-4,9,11-oestratriene acetate; TBA) in conjunction with oestradiol-17 $\beta(\mathrm{Oe})$ has been shown to increase live-weight gain and carcass weight in steers (Heitzman, 1980) and wether lambs (Coelho et al. 1981), increasing protein deposition in these animals. Similar effects have been reported after implantation with zeranol (6-(6, 10-dihydro-oxyundecyl) $\beta$-resorcyclic acid- $\mu$-lactone; Borger et al. 1973; Maund, 1976), a non-steroidal anabolic agent of fungal origin.

Tissue proteins show considerable turnover allowing protein concentrations to be changed by variations in the rates of protein synthesis and degradation (see, for example, Schimke, 1970; Goldberg \& Dice, 1974). In rats alterations in protein synthesis (Millward et al. 1976) and protein degradation (Millward et al. 1975) have been reported to bring about changes in skeletal muscle mass.

We have previously reported that TBA increases growth rate in female rats, decreasing protein synthesis and protein degradation (Vernon \& Buttery, 1976, 1978a,b) and decreasing the 'free' activity of the lysosomal protease cathepsin $\mathrm{D}(E C$ 3 . 4 .23 . 5) (Vernon \& Buttery, 1981). Muscle RNA concentration was increased while muscle RNA activity was decreased (Vernon \& Buttery, 1978a).

It has previously been shown that anabolic agents do not always act similarly in rats and ruminants; for example, diethylstilboestrol increases growth rate in cattle (Heitzman, 1980) but decreases growth rate in male and castrate male rats (Moffit et al. 1975); and treatment with TBA, which increases growth rate in steers (Heitzman, 1980) does not increase growth rate in castrate male rats (Vernon \& Buttery, 1978b). It is therefore important to extend studies on protein metabolism after treatment with anabolic agents in ruminants.

In the present paper we have examined some aspects of protein metabolism and tissue composition in wether lambs after implanting TBA and Oe, and entire female lambs after 


\section{P. A. Sinnett-Smith, Nicola W. Dumelow And P. J. Buttery}

implanting TBA or zeranol. This study indicates that TBA alters protein metabolism in lambs in a similar manner to that previously reported in rats.

\section{MATERIALS AND METHODS}

\section{Animals}

Expt 1. Castrate male lambs (Suffolk cross) were purchased from a local farm. Animals were randomly assigned to treatment and control groups, seven control and eight treated, and individually penned. The treatment group were implanted subcutaneously at the base of the ear with $140 \mathrm{mg}$ TBA and $20 \mathrm{mg}$ Oe (Revalor; Roussel-Uclaf, Paris) 8 weeks before slaughter. Throughout the trial period animals were allowed free access to a pelleted feed (g/kg: barley 225 , oats 450 , grassmeal 200 , Wrightmin mineral mix 25 , Nutramol 100, dry matter 873.5 , crude protein $(\mathrm{N} \times 6.25)$ corrected for moisture 134.4$)$ and water. Feed intake and animal weights were measured weekly.

Expt 2. Female lambs (Suffolk cross) were purchased from a local farm. Animals were randomly assigned to three groups, unimplanted controls (five animals), implanted with $80 \mathrm{mg}$ TBA (Finaplix; Hoechst UK Ltd, Hounslow, Middlesex) (six animals) and implanted with $12 \mathrm{mg}$ zeranol (Ralgro, Crown Chemical Co. Ltd, Lamberhurst, Kent) (six animals). Care of the animals was the same as for Expt 1.

In both experiments the dose of the anabolic agent was chosen in order to give maximal metabolic effect in a short period.

\section{Methods}

Protein metabolism. The fractional synthesis rate of mixed tissue proteins was determined by the constant infusion method, including calculations as described by Garlick et al. (1973), except that L-[4, 5- $\left.{ }^{3} \mathrm{H}\right]$ leucine was used, and individual $R$ values were determined for each sheep and used in the calculations (see Discussion). Four weeks after implantation, cannulas (Portex, Hythe, Kent; internal diameter $1.00 \mathrm{~mm}$ ) were inserted into both jugular veins. Animals were infused with $\mathrm{L}-\left[4,5-{ }^{3} \mathrm{H}\right]$ leucine (Amersham International, Amersham, Bucks.) diluted to $10 \mu \mathrm{Ci} / \mathrm{ml}$ in $130 \mu \mathrm{M}$-leucine $(76 \mu \mathrm{Ci} / \mu \mathrm{mol})$ at approximately $8 \mathrm{ml} / \mathrm{h}$, the actual rate being measured for each animal, for $6 \mathrm{~h}$ via one cannula. Blood samples (approximately $5 \mathrm{ml}$ ) were withdrawn at $30 \mathrm{~min}$ intervals during the infusion via the second cannula. At the end of the infusion period animals were anaesthetized (Sagital, sodium pentobarbitone, $60 \mathrm{mg} / \mathrm{ml}$; May and Baker, Dagenham, Essex) and approximately $30 \mathrm{~g}$ back muscle (longissimus dorsi), from the near base of the ribs, and a liver sample excised. A portion of the muscle was taken for cathepsin D assay and the rest frozen in liquid nitrogen and stored at $-20^{\circ}$ until used for all other analyses.

For each sheep the plasma free leucine specific radioactivity was determined in at least the final three samples to ensure isotopic steady-state had been reached. Analysis of the entire build-up curve from one control sheep indicated that plateaux in plasma specific radioactivity would be expected well before $6 \mathrm{~h}$.

The preparation of samples for determination of tissue protein-bound and intracellular free leucine was as described by Garlick et al. (1973) with the addition of norleucine to a final concentration of $0 \cdot 1 \mu \mathrm{mol} / \mathrm{ml}$ as internal standard. Plasma was deproteinized with sulphosalicylic acid $(6 \% \mathrm{w} / \mathrm{v}$ containing $0.2 \mu \mathrm{mol} / \mathrm{ml}$ norleucine $), 1: 1$ with plasma, the supernatant fraction freeze-dried and stored at $-20^{\circ}$ until analysed. The specific radioactivity of tissue and plasma leucine was determined by split-stream amino acid analysis using the separation system devised by Atkin \& Ferdinand (1970). Skeletal muscle cathepsin D activity was measured in fresh muscle samples by the method of Barrett (1972) as modified by Jefferson et al. (1977). Total cathepsin D activity was measured after addition of Triton $\mathrm{X}-100$ to the homogenate. During the course of these assays a fault occurred in one of the 
reagents leading to the failure of some assays. The plasma leucine flux was calculated as described by Garlick et al. (1973). The RNA activity was calculated by dividing the protein fractional synthesis rate by the RNA:protein value (Millward et al. 1975).

Tissue composition. Skeletal muscle protein content was measured by the method of Lowry et al. (1951); the values obtained were similar to those obtained by the Kjeldahl method in a previous experiment (M. H. Hollom and P. J. Buttery, unpublished observations). Tissue RNA content was measured by reaction with orcinol (Kerr \& Seraidorian, 1945) following tissue preparation as described by Munro \& Fleck (1969). Tissue DNA content was determined by reaction with diphenylamine (Umbreit et al. 1972) after acid hydrolysis $\left(0.7 \mathrm{M}\right.$-perchloric acid, $\left.90^{\circ}, 15 \mathrm{~min}\right)$ of the precipitate obtained from the RNA extraction. At the same time tissue water content was determined by drying approximately $1 \mathrm{~g}$ of the tissue to constant weight in a vacuum oven at $60^{\circ}$ (Vernon \& Buttery, 1976).

Hormone assays. Plasma concentrations of 3,5,3'-triiodothyronine $\left(\mathrm{T}_{3}\right)$ and thyroxine $\left(\mathrm{T}_{4}\right)$ were determined using Amerlex $T_{3}$ and $T_{4}$ radioimmunoassay kits (Amersham International).

\section{Statistics}

Results are expressed as mean values with their standard errors or mean values and the pooled standard error of the difference. The significance of differences between groups was determined by Student's $t$ test (Expt 1) or by analysis of variance (Expt2). Treatments were considered to be not significantly different at $P>0 \cdot 1$.

For all analyses, where the number of observations is less than the original number of animals, this is due to loss of samples at some point during analysis unless otherwise stated.

\section{RESULTS \\ Expt 1}

The effects of treatment with TBA and Oe on weight gain are shown in Table 1. Implanted animals showed a significantly increased growth rate $(P<0.01)$ over the treatment period, confirming previously reported results (Coelho et al. 1981). Treated animals also showed considerably improved food conversion efficiency. Surprisingly, food intake was not affected (Table 1).

No changes in muscle protein or DNA concentrations were observed after hormone treatment (Table 2). Muscle RNA concentration was significantly decreased $(P<0.05)$ after 8 weeks of treatment with TBA and Oe. The total activity of the cathepsin D in muscle

Table 1. Expt 1. The effect of trenbolone acetate $(T B A)$ and oestradiol-17 $\beta(O e)$ in combination on weight gain and food conversion efficiency in wether lambs

(Mean values with their standard errors; no. of animals in parentheses. Animals were slaughtered 8 weeks after implanting the treatment group with $140 \mathrm{mg}$ TBA and $20 \mathrm{mg} \mathrm{Oe}$ )

\begin{tabular}{|c|c|c|c|c|}
\hline & \multicolumn{2}{|c|}{ Control (7) } & \multicolumn{2}{|c|}{ TBA and Oe (8) } \\
\hline & Mean & $\mathrm{sE}$ & Mean & $\mathrm{SE}$ \\
\hline Initial wt $(\mathrm{kg})$ & $40 \cdot 2$ & 0.81 & $41 \cdot 0$ & 0.87 \\
\hline Final wt (kg) & $52 \cdot 0$ & 1.46 & $60 \cdot 4^{* *}$ & 1.62 \\
\hline Wt gain (kg) & 11.57 & 1.39 & $19 \cdot 4^{* *}$ & $1 \cdot 60$ \\
\hline Food intake $\uparrow(\mathrm{kg})$ & $112 \cdot 8$ & 8.44 & $118 \cdot 3$ & $5 \cdot 75$ \\
\hline FCE & $10 \cdot 34$ & 1.07 & $6.05^{* *}$ & 0.37 \\
\hline
\end{tabular}

FCE, food conversion efficiency ( $\mathrm{kg}$ food intake/ $\mathrm{kg}$ body-weight gain).

$\dagger$ Food intake $(\mathrm{kg})$ over the 8 -week trial period.

Mean values were significantly different from control values: ${ }^{* *} P<0.01$. 


\section{P. A. Sinnett-Smith, Nicola W. Dumelow and P. J. Buttery}

Table 2. Expt 1. The effect of trenbolone acetate $(T B A)$ and oestradiol-17 $\beta(\mathrm{Oe})$ on tissue composition, cathepsin $D$ (EC 3.4.23 .5) activity and plasma 3,5,3'-triiodothyronine $\left(T_{3}\right)$ and thyroxine $\left(T_{4}\right)$ concentrations in wether lambs

(Mean values with their standard errors; no. of measurements in parentheses. Blood samples for $T_{3}$ and

$T_{4}$ assay were taken on day 30 of the treatment period. Other measurements were made at slaughter,

8 weeks after implantation with $140 \mathrm{mg}$ TBA and $20 \mathrm{mg} \mathrm{Oe}$ )

\begin{tabular}{|c|c|c|c|c|}
\hline & \multicolumn{2}{|c|}{ Control } & \multicolumn{2}{|c|}{ TBA and Oe } \\
\hline & Mean & $\mathrm{SE}$ & Mean & SE \\
\hline \multicolumn{5}{|c|}{ Muscle (mg/g wet wt) } \\
\hline Protein & $292 \cdot 5$ & $1 \cdot 70(4)$ & $298 \cdot 0$ & $11.8 \quad(4)$ \\
\hline RNA & $1 \cdot 2$ & $0.11(7)$ & $0 \cdot 8^{*}$ & $0.08(8)$ \\
\hline DNA & 0.83 & $0.03(7)$ & 0.72 & $0 \cdot 12(8)$ \\
\hline \multicolumn{5}{|c|}{$\begin{array}{l}\text { Cathepsin } D \text { activity } \\
\text { (disintegrations/min } \\
\text { per mg protein) }\end{array}$} \\
\hline Free & $4 \cdot 73$ & $1.47(4)$ & $4 \cdot 48$ & $1 \cdot 11(4)$ \\
\hline Total & $24 \cdot 0$ & $1.63(3)$ & $16 \cdot 3^{*}$ & 1.77 (4) \\
\hline $\mathrm{T}_{3}(\mathrm{ng} / \mathrm{ml}$ plasma $)$ & $2 \cdot 17$ & $0.024(7)$ & 1.95 & $0.191(8)$ \\
\hline $\mathrm{T}_{\mathrm{q}}(\mathrm{ng} / \mathrm{ml}$ plasma $)$ & $91 \cdot 1$ & $15 \cdot 65(7)$ & $62 \cdot 8$ & $4.82(8)$ \\
\hline
\end{tabular}

Significantly different from controls: $* P<0.05$.

showed a significant decrease $(P<0.05)$ after treatment with TBA (Table 2$)$; free cathepsin $\mathrm{D}$ activity was not affected; however, during this trial problems with the cathepsin $\mathrm{D}$ assay were encountered. Plasma levels of $T_{3}$ and $T_{4}$ were not significantly different in controls and treated animals at day 30 , although $T_{4}$ levels did show a small non-significant decrease in treated animals (Table 2).

\section{Expt 2}

Treatment of entire female sheep with TBA or zeranol resulted in a significant increase in weight gain (Table 3). Both treatment groups showed significantly larger weight gains than

\section{Table 3. Expt 2. The effect of trenbolone acetate (TBA) or zeranol treatment on weight gain in entire female lambs}

(Mean values with pooled standard error of the difference by analysis of variance; no. of animals in parentheses. Treated animals were implanted with $80 \mathrm{mg}$ TBA or $12 \mathrm{mg}$ zeranol 4 weeks before slaughter)

\begin{tabular}{lccccccc}
\hline \hline & & & & \multicolumn{2}{c}{ Significance of comparisons } \\
& $\begin{array}{c}\text { Control } \\
(5)\end{array}$ & $\begin{array}{c}\text { TBA } \\
(6)\end{array}$ & $\begin{array}{c}\text { Zeranol } \\
(6)\end{array}$ & SED & $\begin{array}{c}\text { Control } \\
v . \text { TBA }\end{array}$ & $\begin{array}{c}\text { Control } \\
v . \text { zeranol }\end{array}$ & $\begin{array}{c}\text { TBA } v . \\
\text { zeranol }\end{array}$ \\
& 30.6 & 31.7 & 31.2 & 2.58 & NS & NS & NS \\
Initial wt (kg) & 36.4 & 42.4 & 40.6 & 3.58 & NS & NS & NS \\
Final wt (kg) & 5.8 & 10.7 & 9.4 & 1.49 & $P<0.01$ & $P<0.05$ & NS \\
Wt gain (kg) & 36.6 & 50.8 & $49.4 \ddagger$ & 7.46 & NS & NS & NS \\
Food intake† (kg) & 6.1 & 4.9 & $5.0 \ddagger$ & 0.49 & $P<0.05$ & $P<0.05$ & NS \\
FCE & & & & & & &
\end{tabular}

NS, not significant.

FCE, food conversion efficiency ( $\mathrm{kg}$ food intake $/ \mathrm{kg}$ body-weight gain).

$\dagger$ Food intake (kg) over the 4-week trial period.

$\ddagger$ Five values only, one sheep omitted due to food spillage. 
Table 4. Expt 2. Alterations in tissue composition in female lambs treated with trenbolone acetate $(T B A)$ or zeranol

(Mean values with pooled standard error of the difference by analysis of variance; no. of observations in parentheses. Animals were slaughtered 4 weeks after implantation with $80 \mathrm{mg}$ TBA or $12 \mathrm{mg}$ zeranol)

\begin{tabular}{|c|c|c|c|c|c|c|c|}
\hline & \multirow[b]{2}{*}{$\begin{array}{c}\text { Control } \\
\text { (5) }\end{array}$} & \multirow[b]{2}{*}{$\begin{array}{c}\text { TBA } \\
(6)\end{array}$} & \multirow[b]{2}{*}{$\begin{array}{l}\text { Zeranol } \\
(6)\end{array}$} & \multirow[b]{2}{*}{ SED } & \multicolumn{3}{|c|}{ Significance of comparisons } \\
\hline & & & & & $\begin{array}{l}\text { Control } \\
v . \text { TBA }\end{array}$ & $\begin{array}{c}\text { Control } \\
\text { v. zeranol }\end{array}$ & $\begin{array}{c}\text { TBA } v \\
\text { zeranol }\end{array}$ \\
\hline \multicolumn{8}{|c|}{ Muscle (mg/g wet wt) } \\
\hline Protein & $265 \cdot 0$ & $258 \cdot 8$ & $285 \cdot 7$ & $35 \cdot 77$ & NS & NS & NS \\
\hline RNA & 0.49 & $0-28$ & $0 \cdot 16$ & 0.085 & $P<0.05$ & $P<0.01$ & NS \\
\hline DNA & 0.58 & 0.35 & 0.30 & 0.071 & $P<0.01$ & $P<0.01$ & NS \\
\hline $\begin{array}{l}\text { Muscle water } \\
\text { content }(\mathrm{g} / \mathrm{gk})\end{array}$ & 691 & $666^{*}$ & 688 & 86 & $P<0.02$ & NS & NS \\
\hline \multicolumn{8}{|c|}{ Liver (mg/g wet wt) } \\
\hline Protein & $152 \cdot 0$ & $156 \cdot 4$ & $163 \cdot 3$ & $8 \cdot 63$ & NS & NS & NS \\
\hline RNA & $2 \cdot 61$ & $2 \cdot 56$ & $2 \cdot 46$ & 0.62 & NS & NS & NS \\
\hline DNA & $4 \cdot 89$ & 4.94 & $4 \cdot 75$ & 0.70 & NS & NS & NS \\
\hline
\end{tabular}

* Five values.

NS, not significant.

Table 5. Expt 2. Tissue and plasma leucine concentrations and tissue leucine relative specific radioactivities in female lambs treated with trenbolone acetate $(T B A)$ or zeranol

(Mean values with pooled standard error of the difference by analysis of variance; no. of observations in parentheses. The specific radioactivity of plasma free leucine has been given the value of unity and that of muscle and liver homogenates expressed relatively)

\begin{tabular}{|c|c|c|c|c|c|c|c|}
\hline & \multirow[b]{2}{*}{ Control } & \multirow[b]{2}{*}{ TBA } & \multirow[b]{2}{*}{ Zeranol } & \multirow[b]{2}{*}{ SED } & \multicolumn{3}{|c|}{ Significance of comparisons } \\
\hline & & & & & $\begin{array}{l}\text { Control } \\
\text { v. TBA }\end{array}$ & $\begin{array}{l}\text { Control } \\
\text { v. zeranol }\end{array}$ & $\begin{array}{l}\text { TBA } y \text {. } \\
\text { zeranol }\end{array}$ \\
\hline \multicolumn{8}{|l|}{ Muscle } \\
\hline \multicolumn{8}{|l|}{$\begin{array}{l}\text { Homogenate free- } \\
\text { leucine }\end{array}$} \\
\hline $\begin{array}{l}(\mu \mathrm{mol} / \mathrm{g} \text { wet } \mathrm{wt}) \\
\text { Relative SRA }\end{array}$ & $\begin{array}{l}0.089(5) \\
0.721(5)\end{array}$ & $\begin{array}{l}0.071(5) \\
0.929(5)\end{array}$ & $\begin{array}{l}0.115(5) \\
0.640(5)\end{array}$ & $\begin{array}{l}0.0131 \\
0.221\end{array}$ & NS & $P<0.10$ & $\begin{array}{c}P<0.01 \\
\text { NS }\end{array}$ \\
\hline \multicolumn{8}{|l|}{ Liver } \\
\hline \multicolumn{8}{|l|}{$\begin{array}{l}\text { Homogenate free- } \\
\text { leucine } \\
\text { concentration }\end{array}$} \\
\hline$(\mu \mathrm{mol} / \mathrm{g}$ wet $\mathrm{wt})$ & $0 \cdot 150(5)$ & $0 \cdot 154(6)$ & $0 \cdot 177(6)$ & 0.025 & NS & NS & NS \\
\hline Relative SRA & $0.992(5)$ & $0.907(5)$ & $0.868(5)$ & $0 \cdot 159$ & NS & NS & NS \\
\hline $\begin{array}{l}\text { Plasma free-leucine } \\
\text { concentration } \\
(\mu \mathrm{mol} / \mathrm{ml})\end{array}$ & $0.095(5)$ & $0 \cdot 112(5)$ & $0 \cdot 155(5)$ & 0.0178 & NS & $P<0.01$ & $P<0.05$ \\
\hline
\end{tabular}

SRA, specific radioactivity.

NS, not significant.

controls (TBA, $P<0.01$; zeranol, $P<0.05$ ). Food intake was not significantly altered by treatment with TBA or zeranol (Table 3) but the food conversion efficiencies of both TBAand zeranol-treated animals were significantly improved $(P<0.05)$ over controls (Table 3$)$.

Skeletal muscle protein content $(\mathrm{mg} / \mathrm{g}$ wet weight) was not affected by treatment with TBA or zeranol (Table 4). Muscle RNA and DNA concentrations were both significantly 
Table 6. Expt 2. The effect of trenbolone acetate $(T B A)$ or zeranol on protein fractional synthesis rates, RNA activity, leucine fux and cathepsin D (EC 3.4.23.5) activity in entire female lambs

(Mean values with pooled standard error of the difference by analysis of variance; no. of observations in parentheses. Lambs were implanted with TBA $(80 \mathrm{mg})$ or zeranol $(12 \mathrm{mg}) 4$ weeks before slaughter or retained as unimplanted controls)

\begin{tabular}{|c|c|c|c|c|c|c|c|}
\hline & \multirow[b]{2}{*}{ Control } & \multirow[b]{2}{*}{ TBA } & \multirow[b]{2}{*}{ Zeranol } & \multirow[b]{2}{*}{ SED } & \multicolumn{3}{|c|}{ Significance of comparisons } \\
\hline & & & & & $\begin{array}{l}\text { Control } \\
v . \text { TBA }\end{array}$ & $\begin{array}{l}\text { Control } \\
v . \text { zeranol }\end{array}$ & $\begin{array}{c}\text { TBA } \\
v . \text { zerano }\end{array}$ \\
\hline \multicolumn{8}{|l|}{ Muscle } \\
\hline $\begin{array}{l}\text { Protein FSR }(/ d) \\
\text { (from homogenate } \\
\text { free leucine SRA) }\end{array}$ & $0.060(5)$ & $0.039(6)$ & $0 \cdot 041(5)$ & 0.010 & $P<0 \cdot 10$ & NS & NS \\
\hline $\begin{array}{l}\text { Protein FSR }(/ \mathrm{d}) \\
\text { (from plasma free } \\
\text { leucine SRA) }\end{array}$ & $0.049(5)$ & $0.033(5)$ & $0 \cdot 028(5)$ & 0.0073 & $P<0 \cdot 10$ & $P<0.02$ & NS \\
\hline $\begin{array}{l}\text { RNA activity } \\
\text { (mg protein/d per } \\
\text { mg RNA) }\end{array}$ & $28 \cdot 7(5)$ & $36 \cdot 6(5)$ & $65 \cdot 2(5)$ & $11 \cdot 72$ & NS & $P<0.02$ & $P<0.05$ \\
\hline \multicolumn{8}{|l|}{$\begin{array}{l}\text { Cathepsin D activity } \\
\text { (disintegrations/ } \\
\text { min per mg protein) }\end{array}$} \\
\hline Free & $3.79(5)$ & $2.06(4)$ & $2 \cdot 00(3)$ & 0.70 & $P<0.05$ & $P<0.05$ & NS \\
\hline Total & $15 \cdot 05(5)$ & $14.02(5)$ & $16.00(6)$ & 1.74 & NS & NS & NS \\
\hline \multicolumn{8}{|c|}{ - } \\
\hline $\begin{array}{l}\text { Protein FSR }(/ d) \\
\text { (from homogenate } \\
\text { free leucine SRA) }\end{array}$ & $0.309(5)$ & $0 \cdot 281(5)$ & $0.262(6)$ & 0.059 & NS & NS & NS \\
\hline $\begin{array}{l}\text { Protein FSR }(/ d) \\
\text { (from plasma free } \\
\text { leucine SRA) }\end{array}$ & $0 \cdot 291(5)$ & $0 \cdot 238(5)$ & $0.219(5)$ & 0.0406 & NS & NS & NS \\
\hline $\begin{array}{l}\text { RNA activity } \\
\text { (mg protein/d per } \\
\text { mg RNA) }\end{array}$ & $14 \cdot 9(5)$ & $16.9(5)$ & $14 \cdot 2(6)$ & $3 \cdot 00$ & NS & NS & NS \\
\hline $\begin{array}{l}\text { Plasma leucine } \\
\text { flux } \\
\text { ( } \mu \text { mol/h per } \mathrm{kg} \\
\text { body-wt) }\end{array}$ & $419(5)$ & $463(5)$ & $335(4)$ & $95 \cdot 9$ & NS & NS & NS \\
\hline
\end{tabular}

FSR, fractional synthesis rate.

SRA, specific radioactivity.

NS, not significant.

decreased after TBA (RNA, $P<0.05$; DNA, $P<0.01$ ) and zeranol (RNA and DNA, $P<0.01$ ) treatment (Table 4). The tissue water content was also significantly reduced after TBA treatment $(P<0.02$, Table 4$)$ but not altered by zeranol treatment. This result implies that any increase in tissue weight was not due to increased water retention. Liver protein, RNA and DNA content (Table 4) were not significantly altered by treatment with TBA or zeranol. The skeletal muscle homogenate free leucine concentration of zeranol-treated animals was significantly greater $(P<0 \cdot 01)$ than for TBA-treated animals; however, compared with controls the difference was significant only at $P<0 \cdot 10$ (Table 5). The liver homogenate free leucine concentration was not altered by TBA or zeranol treatment (Table 5). Zeranol treatment significantly increased plasma leucine concentration as compared with controls $(P<0.01)$ and TBA-treated animals $(P<0.05)$.

The relative specific radioactivities for muscle and liver free leucine, compared with that in plasma, did not show any significant change after TBA or zeranol treatment (Table 5). 
The mixed muscle protein fractional synthesis rate in TBA-treated animals was significantly lower than in control animals at $P<0 \cdot 10$ (Table 6) when calculated using the homogenate or plasma free leucine specific radioactivity. The protein fractional synthesis rate in zeranol-treated animals was significantly different from control values when calculated from the plasma free leucine specific radioactivity; when calculated from the homogenate free leucine specific radioactivity the value was again lower but did not reach significance (Table 6). Skeletal muscle free-cathepsin $D$ activity was significantly reduced after treatment with TBA and zeranol $(P<0.05)$ (Table 6). Total cathepsin $\mathrm{D}$ activity did not show any significant variation (Table 6). The activity of skeletal muscle RNA was not significantly affected by TBA treatment but was increased $(P<0.02)$ by treatment with zeranol.

The mixed liver protein fractional synthesis rate (Table 6 ) was not significantly affected by either TBA or zeranol treatment regardless of the method of calculation. The activity of liver RNA also did not change after hormone treatment (Table 6).

The plasma leucine flux per unit body-weight (Table 6) was not significantly affected by TBA or zeranol treatment.

\section{DISCUSSION}

In skeletal muscle it is not clear whether protein synthesis or degradation is the control point of growth (Millward et al. 1975, 1976). In entire female rats both protein synthesis and degradation are reduced after TBA treatment, with the decrease in degradation being greater, resulting in increased muscle mass (Vernon \& Buttery, 1976, 1978 $a, b$ ). Treatment of lambs with TBA or zeranol increased weight gains (Tables 1 and 3) and protein deposition (Borger et al. 1973; Coelho et al. 1981). Treatment with TBA and Oe increased carcass weight and increased carcass lean in whether lambs kept at grass, with a diet supplement (N. W. Dumelow and P. J. Buttery, unpublished observations). In the present study the mixed skeletal muscle protein synthesis rate was reduced in female lambs after TBA treatment $(P<0 \cdot 1)$. While it is difficult to draw firm conclusions from differences at this significance level, the similarity of these results to those in the rat (Vernon \& Buttery, 1976, $1978 a, b)$ indicated that in these animals increased muscle protein synthesis was not responsible for the increased weight gain. All indications are that zeranol also decreased muscle protein fractional synthesis rate, again implying that the increased growth rate is brought about by some means other than increased protein synthesis. The absence of effects on liver protein synthesis indicates that these effects may be selective. The results with TBA closely resemble those observed in the rat (Vernon \& Buttery 1976, 1978a).

In contrast to the reduction in muscle protein synthesis after implant treatment, plasma leucine flux, an indicator of total body protein turnover (Garlick et al. 1973), was not significantly affected by TBA or zeranol treatment. In steers treated with TBA and Oe, no change in whole-body protein synthesis was observed; these results were, however, corrected for a decrease in leucine oxidation (Lobley et al. 1982). It was not possible to determine leucine oxidation in this study. Great care must be taken in interpreting whole-body protein synthesis values following treatments which are known to have differential effects on tissues (see Vernon \& Buttery, 1976).

Accepting that there was an increased protein deposition in the lean of the treated carcasses (Coelho et al. 1981) and that muscle protein synthesis was decreased, then increased deposition must have been brought about by decreased protein degradation.

Direct measurement of muscle protein breakdown in sheep is difficult. The 3methylhistidine technique is not reliable in sheep (Harris \& Milne, 1980; Coward \& Buttery, 1982). Cathepsin D activity in muscle has been used to give some indication of muscle protein degradation. The free cathepsin D activity is an indicator of lysosomal protein degradation (Barrett, 1972; Jefferson et al. 1977). Free cathepsin D activity is reduced in female rats after treatment with TBA (Vernon \& Buttery, 1981). Excretion of 3- 


\section{P. A. Sinnett-Smith, Nicola W. Dumelow and P. J. Buttery}

methylhistidine, an indication of myofibrillar protein degradation, is also decreased in these rats (Vernon \& Buttery, 1978b), as was protein degradation measured using $\mathrm{NaH}^{14} \mathrm{CO}_{3}$ (Vernon \& Buttery, 1976). In entire female lambs treated with TBA or zeranol, free cathepsin D activities were significantly reduced compared with controls (Table 6), indicating a reduction in lysosomal protein degradation. In castrate male lambs treated with TBA and Oe, free cathepsin D activity was not affected; however total cathepsin D activity was significantly reduced (Table 2). A correlation between muscle protein degradation and total cathepsin D activity in the perfused rat hemicorpus has been reported (Rannels \& Jefferson, 1980). The reduction in total cathepsin D availability observed in this study may therefore indicate a reduced capacity for lysosomal proteolysis after TBA treatment. However, as indicated previously (p. 226) there were assay problems during the experiments; further experimentation is therefore required to confirm these observations.

The muscle homogenate free-leucine concentration and plasma free-leucine concentration were not reduced by TBA treatment, therefore the reduction in protein synthesis observed cannot be attributed to a reduction in the availability of this precursor. The same can be said for zeranol treatment: although more leucine was available from both plasma and homogenate free leucine pools, the muscle protein fractional synthesis rate was reduced. These results are important since leucine has been implicated in the control of protein synthesis, increased concentrations of leucine increasing protein synthesis (Goldberg et al. 1974).

An interesting observation was that the plasma free-leucine concentration $(\mu \mathrm{mol} / \mathrm{ml}$ plasma) was greater than that in the tissue homogenate $(\mu \mathrm{mol} / \mathrm{g}$ tissue; Table 5$)$. We have also observed that in perfused diaphragm preparations, homogenate free-leucine concentrations were very close to those in normal sheep plasma (Coward \& Buttery, 1982; Tao et al. 1974). A similar concentration difference between muscle and plasma free leucine has been reported in the rat (Lunn et al. 1976). This small variation in concentration between homogenate and plasma free leucine suggests that when determining $R$ values for muscle protein synthesis calculations there is no need to correct for extracellular leucine, especially bearing in mind the relative insensitivity to small variations in $R$ values of the muscle protein synthesis calculation (Waterlow et al. 1978). The decrease in DNA content after TBA or zeranol treatment (Table 4) may indicate that increased growth is due to cell enlargement, i.e. cell hypertrophy rather than hyperplasia. This cell enlargement is probably not due to increased water retention, since tissue water content was not increased by hormonal treatment (Table 4).

The mode of action of anabolic agents is at present not clear. TBA is essentially androgenic (Hoffman, 1980). In rats and cows, plasma TBA is deacetylated to trenbolone (Pottier et al. 1981), a steroid which has a similar structure to testosterone and has been shown to bind to the rat prostate gland receptor (Raymond et al. 1981). Cytosolic receptors for androgenic hormones have been identified in skeletal muscle from rats (Dubé et al. 1976; Snochowski et al. 1980), pigs (Snochowski et al. 1981 a) and humans (Snochowski et al. $1981 b$ ). The methyl derivative of trenbolone, $17 \alpha$-methyl-trienolone (17 $\beta$-hydroxy-17 $\alpha$ methyl-oestra-4,9,11-triene-3-one), binds to the cytosolic androgen receptors of rat, porcine and human skeletal muscle (Snochowski et al. 1980, Snochowski et al. 1981 $a, b$ ), indicating that trenbolone may have a direct action in skeletal muscle. However, treatment with testosterone has been reported to stimulate RNA synthesis in rat skeletal muscle (Breuer \& Florini, 1966), implying increased protein synthesis, unlike TBA treatment (Table 5; Vernon \& Buttery, 1976, 1978a). In contrast, the anabolic agent nandrolone phenylpropionate $(19$, nor-17 $\beta$-hydroxy-3-keto-androstene-17-phenyl propionate), which is also very similar in structure to testosterone, increases rat skeletal muscle protein synthesis and, to a lesser extent, increases muscle protein degradation (Dumelow et al. 1982). These results 
indicate that not all androgenic anabolic agents act in the same way. Nandrolone phenylpropionate may act as an agonist when bound to the endogenous androgen receptor. It appears that it may be productive to look for the muscle action of TBA in areas other than those associated with its androgenicity.

TBA may also act by altering the concentrations of endogenous hormones. For example, in sheep, TBA treatment has been reported to reduce plasma $T_{4}$ concentration while having no effect on growth hormone or insulin (Donaldson et al. 1981). No significant effect on $T_{3}$ or $T_{4}$ concentrations was observed in the present, albeit limited, study.

Zeranol has been reported to have an oestrogenic action on the sheep uterus in vitro, inhibiting oestradiol binding to its receptor (Peck \& Chesworth, 1977). It has been suggested that the oestrogenic anabolic agents may act by altering the levels of endogenous hormones. Treatment with Oe increases insulin levels in cattle and sheep (Heitzman, 1980) and oestrogens stimulate insulin synthesis and secretion from isolated rat pancreatic islets (Faure \& Sutter-Dub, 1979). Insulin, however, increases protein synthesis in skeletal muscle (see, for example, Young, 1980) unlike zeranol in this study. There is also evidence of oestrogen binding to skeletal muscle from male and female rats (Dubé et al. 1976, Dahlberg, 1982).

In conclusion, our results suggest that in sheep, TBA has similar effects on protein metabolism to those in the rat. The effects of zeranol and TBA appear to be similar.

The authors thank Miss C. A. Palmer, Mrs J. Simpson, Miss C. Essex and Mr D. Bozon for technical assistance, and the Agricultural Research Council for financial support. N.W.D. is a Ministry of Agriculture, Fisheries and Food postgraduate student. RousselUclaf, Hoechst UK and Crown Chemical Co. are thanked for their donations of Revalor, Finaplix and Ralgro.

\section{REFERENCES}

Atkin, G. E. \& Ferdinand, W. (1970). Analytical Biochemistry 38, 313-329.

Barrett, A. J. (1972). In Lysosomes: a Laboratory Handbook, pp. 42-135 [J. T. Dingle, editor]. Amsterdam: North-Holland.

Borger, M. L., Wilson, L. L., Sink, J. D., Ziegler, J. H. \& Davis, S. L. (1973). Journal of Animal Science 36, $706-711$. Breuer, C. B. \& Florini, J. R. (1966). Biochemistry, New York 5, 3857-3865.

Coelho, J. F. S., Galbraith, H. \& Topps, J. H. (1981). Animal Production 32, 261-266.

Coward, B. J. \& Buttery, P. J. (1982). Journal of Agricultural Science, Cambridge 98, 307-316.

Dahlberg, E. (1982). Biochimica et Biophysica Acta 717, 65-75.

Donaldson, I. A., Hart, 1. C. \& Heitzman, R. J. (1981). Research in Veterinary Science 30, 7-13.

Dubé, J. Y., Lesage, R. \& Tremblay, R. R. (1976). Canadian Journal of Biochemistry 54, 50-55.

Dumelow, N. W., Pearson, J. T., Essex, C. P. \& Buttery, P. J. (1982). Proceedings of the Nutrition Society 41,57 A.

Faure, A. \& Sutter-Dub, M.-Th. (1979). Journal of Physiology, Paris 75, 289-295.

Garlick, P. J., Millward, D. J., James, W. P. T. \& Waterlow, J. G. (1973). Biochemical Journal 136, $935-945$.

Goldberg, A. L. \& Dice, J. F. (1974). Annual Reviews in Biochemistry 43, 835-869.

Goldberg, A. L., Howell, E. M., Li, J. B., Martel, S. B. \& Prouty, W. F. (1974). Federation Proceedings 33, 1112-1120.

Harris, C. I. \& Milne, G. (1980). British Journal of Nutrition 44, 129-140.

Heitzman, R. J. (1980). In Protein Deposition in Animals, pp. 193-203 [P. J. Buttery and D. B. Lindsay, editors]. London: Butterworths.

Hoffman, B. (1980). In Protein Deposition in Animals, pp. 205-214 [P. J. Buttery and D. B. Lindsay, editors]. London: Butterworths.

Jefferson, L. S., Li, J. B. \& Rannels, M. B. (1977). Journal of Biological Chemistry 252, 1476-1483.

Kerr, S. E. \& Seraidorian, K. (1945). Journal of Biological Chemistry 159, 211-225.

Lobley, J., Smith, S., Mollison, G., Connell, A. \& Galbraith, H. (1982). Proceedings of the Nutrition Society 41, $28 \mathrm{~A}$.

Lowry, O. H., Rosebrough, N. J., Farr, A. C. \& Randall, R. J. (1951). Journal of Biological Chemistry 193, $265-275$.

Lunn, P. G., Whitehead, R. G. \& Baker, B. A. (1976). British Journal of Nutrition 36, 219-230.

Maund, B. A. (1976). Animal Production 22, 149.

Millward, D. J., Garlick, P. J., James, W. P. T., Nnanyelugo, D. O. \& Ryatt, S. S. (1973). Nature 241, $204-205$.

Millward, D. J., Garlick, P. J., Nnanyelugo, D. O. \& Waterlow, J. C. (1976). Biochemical Journal 156, $185-188$. 


\section{P. A. Sinnett-Smith, Nicola W. Dumelow and P. J. Buttery}

Millward, D. J., Garlick, P. J., Stewart, R. J. C., Nnanyelugo, D. O. \& Waterlow, J. (1975). Biochemical Journal 150, 235-243.

Moffit, P. E., Wilson, G. R. \& Preston, R. L. (1975). Proceedings of the Society for Experimental Biology and Medicine 148, 650-652.

Munro, H. N. \& Fleck, A. (1969). In Mammalian Protein Metabolism, vol. 3, pp. 424-525 [H. N. Munro, editor]. New York: Academic Press.

Peck, D. N. \& Chesworth, J. M. (1977). Hormone and Metabolic Research 9, 531-532.

Pottier, J., Cousty, C., Heitzman, R. J. \& Reynold, I. P. (1981). Xenobiotica 11, 489-500.

Rannels, S. R. \& Jefferson, L. S. (1980). American Journal of Physiology 238, E564-E 572.

Raymond, J. P., Ojasoo, T. \& Labrie, F. (1981). In Mechanisms of Steroid Action, pp. 145-157 [G. P. Lewis and M. Ginsburg, editors]. London: Macmillan.

Schimke, R. T. (1970). In Mammalian Protein Metabolism, vol. 4, pp. 177-228 [H. N. Munro, editor]. New York: Academic Press.

Snochowski, M., Dahlberg, E. \& Gustafsson, J. A. (1980). European Journal of Biochemistry 111, 603-616.

Snochowski, M., Lundstrom, K., Dahlberg, E., Petersson, H. \& Edquist, L. E. (1981 a). Journal of Animal Science 53, 80-90.

Snochowski, M., Saartok, T., Dahlberg, E., Eriksson, E. \& Gustafsson, J. A. (1981b). Journal of Steroid Biochemistry 14, 765-771.

Tao, R. C., Asplund, J. M. \& Kappel, L. C. (1974). Journal of Nutrition 104, 1646-1656.

Umbreit, W. W., Burris, R. H. \& Stauffer, J. F. (1972). Manometric and Biochemical Techniques, 5th ed. Minneapolis: Burgess Publishing Co.

Vernon, B. G. \& Buttery, P. J. (1976). British Journal of Nutrition 36, 575-579.

Vernon, B. G. \& Buttery, P. J. (1978a). British Journal of Nutrition 40, 563-572.

Vernon, B. G. \& Buttery, P. J. (1978b). Animal Production 26, $1-9$.

Vernon, B. G. \& Buttery, P. J. (1981). Proceedings of the Nutrition Society 40, 13 A.

Waterlow, J. L., Garlick, P. J. \& Millward, D. J. (1978). Protein Turnover in Mammalian Tissues and in the Whole Body. Amsterdam: North-Holland.

Young, V. R. (1980). In Protein Deposition in Animals, pp. 167-191 [P. J. Buttery and D. B. Lindsay, editors]. London: Butterworths. 